\title{
Entomological

\section{Biological control of Brevicoryne brassicae by release of Coccinella septempunctata on Alfalfa plant, Medicago sativa}

\author{
Habeeb. M. Al-Solami', Khalid M. Al-Ghamdi'; Ashraf A. H. Mangoud ${ }^{2}$ \\ and Jazem A. Mahyoub ${ }^{1}$ \\ ${ }^{1}$ Faculty of Science, King Abdulaziz University, Jeddah, Saudi Arabia \\ ${ }^{2}$ Plant Protection Research Institute, A.R.C., Dokki, Giza, 12618 Egypt
}

\begin{abstract}
The seven-spotted ladybird, Coccinella septempunctata L. (Coleoptera : Coccinellidae) was released for one time, in early-February on alfalfa plants during 2012 and repeated in 2013, at Jeddah City at rates of 30, 60 and 90 eggs $/ \mathrm{m}^{2}$. On alfalfa plants (lucerne) Medicago sativa L.: during the first season (2012), the reduction percentages in the population of $B$. brassicae increased gradually with elapse of time reaching the maximum. The achieved average reductions in aphid population, B. brassicae were 26.1, 34.0, 44.4, 50.3 and 55.5\% on mid-February, first-March, mid-March, first-April and mid-April (2012), respectively in the first level of release (30 eggs $\left./ \mathrm{m}^{2}\right)$. In addition, the same trend was achieved in the second season (2013). Also, in the second level of release $\left(60 \mathrm{eggs} / \mathrm{m}^{2}\right)$ during the first season (2012), the reduction percentages in the population of B. brassicae increased gradually with elapse of time reaching the maximum. The achieved average reductions in aphid population were 31.7, 43.1, 56.9, 70.7 and 81.3\% on midFebruary, first-March, mid-March, first-April and mid-April, respectively. In addition, the same trend was achieved in the second season (2013). In addition, the same trend was achieved in the third level of release $\left(90 \mathrm{eggs} / \mathrm{m}^{2}\right)$, the reduction percentages in the population of $B$. brassicae increased gradually with elapse of time reaching the maximum. The achieved average reductions in aphid population were 42.0, 53.7, 68.0, 80.0 and 89.8\% on mid-February, first-March, mid-March, first-April and mid-April, respectively. In addition, the same trend was achieved in the second season (2013). The present work has shown that the seven-spotted ladybird, Coccinella septempunctata L. could be used successfully, as a biocontrol agent in an integrated program for controlling $B$. brassicae on alfalfa plants.
\end{abstract}

KEY WORDS: COCCINELLA SEPTEMPUNCTATA L., BREVICORYNE BRASSICAE (L.), ALFALFA PLANTS, MEDICAGO SATIVA L. BIOLOGICAL CONTROL.

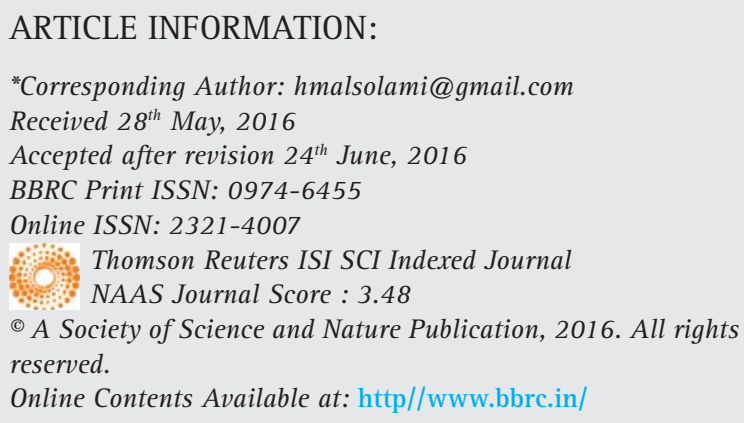




\section{INTRODUCTION}

The cabbage aphid, Brevicoryne brassicae (L.) (Homoptera: Aphididae) is a key pest of various cruciferous crops like cabbage, cauliflower, kale and other such Brassicae species. Cause inflict damage to plants in a number of ways, including malformation of various $\mathrm{m} 2$, parts, gall formation, destruction of foliage, stunted growth, leaf curling, obstruction in assimilation, wilting and sometimes collapse of a $\mathrm{m} 2$,. This aphid is considered one of the most damaging and consistently present pest on cabbage crops (Theunissen, 1989). They are also known to be the vectors of various $\mathrm{m} 2$, viruses (Brunt et al., 1996; Buchen-Usmond 2002). B. brassicae has four instars in the life cycle (Hafez, 1961) has shown that the number of generations per year to be 6 and 11 in Netherland. This aphid feeds in colonies of large numbers on young leaves, mostly on the undersurface and also on tender parts and cause considerable damage. They suck the cell sap from leaves, lowering its vitality, turn yellow and crinkled. In addition, honeydew excretions and transmission of virus diseases are important problems.

The seven-spotted ladybird, C. septempunctata L. (Coleoptera: Coccinellidae) is the commonest ladybird beetle known in Egypt, it is an important predator of many aphid species; eggs and small nymphs of mealybugs, jassids, eggs and larvae of cotton leafworm (Ibrahim, 1948 \&t 1955 and Bilashini et al., 2007). The adults and early stages are often encountered in large numbers on the plants infested with aphids. They feed on these harmful insects and often play a great role in suppressing them under control. Both the adult and larval stages feed on insects harmful to plants, such as aphids and scale insects (Anonymous, 1997). Adults can be consuming up to 100 aphids per day (Arnett et al., 1980). The ladybug kills its prey outright and then devours it, (Waldbauer, 1998). Under field conditions, numerous coccinellids consume nectar, honeydew, pollen, fruit, vegetation, and fungus. These nonprey foods are used by coccinellids to increase survival when prey is scarce, reduce mortality during diapause, fuel migration, and enhance reproductive capacity. Each of these non-prey foods has unique nutritional and defensive characteristics that influence its suitability for lady beetles (Lundgren, 2009, Mangoud and Mahyoub, 2013, Mangoud et al., 2013).

The present work has been aimed to evaluate the management of the cabbage aphid, Brevicoryne brassicae (L.) (Homoptera: Aphididae) infesting alfalfa plants (lucerne) (Medicago sativa L.) by releasing different levels of the seven spotted lady beetle, Coccinella septempunctata (Coleoptera : Coccinellidae) in Jeddah City, Saudi Arabia.

\section{MASS REARING OF THE SEVEN-SPOTTED LADYBIRD, COCCINELLA SEPTEMPUNCTATA AND ITS PREY THE COWPEA APHID, APHIS CRACCIVORA (KOCH)}

\section{Mass rearing of $A$. craccivora as a prey}

A. craccivora is considered the most preferable prey for mass production of $C$. septempunctata. Strong culture of this aphid should be available during the rearing time to maintain the predator rearing process.

The broad bean, Vicia faba seeds were planted in plastic trays $(25 \mathrm{X} 40 \mathrm{X} 15 \mathrm{~cm})$ or foam trays $(60 \mathrm{X} 25 \mathrm{X} 20 \mathrm{~cm}$ with 109 wholes) contained peat muss. The seeds were planted at 1-2 cm deep and followed with irrigation and fertilizers as required. When the first leaflet appeared after about one week from cultivation. Bean leaves were infested with $A$. craccivora which distributed over the new foliage of cultivated trays. Culturing of faba bean plants and artificial aphid infestation was a continuous process carried out at weekly intervals.

The infested trays were followed until the population of $A$. craccivora increased and become suitable for using as prey to the ladybird, C. septempunctata.

A. craccivora colonies were cultured under laboratory conditions $\left(23 \pm 2^{\circ} \mathrm{C}\right.$ and $60 \pm 5 \%$ R.H. $)$ on broad beans (Vicia faba). Such leaves of beans were infested by different stages of aphids and kept under a glass chimney which its upper opening was covered with white muslin. The potted plants were irrigated and fertilized whenever necessary and kept in wooden cages (100X135X135 $\mathrm{cm})$ with nylon gauze sides using the method described by (Mangoud, 2003 and Mangoud and Mahyoub, 2013).

A. craccivora and C. septempunctata instars were originally collected from an agricultural field.

\section{Mass rearing of $C$. septempunctata}

When the population of $A$. craccivora increased and reached to suitable density individuals (approximately 100 individuals $/ \mathrm{m}^{2}$,) on faba bean plants these plants were inoculated with $C$. septempunctata. The stock culture of ladybird was obtained from infested plants and transferred to laboratory. Only 10 adult $\mathrm{O}+10$ adult $Q$ of ladybird (to prevent larval cannibalism) were transferred to rearing cages (30 cm diameter X $25 \mathrm{~cm}$ high) and kept in wooden cages $(100 X 135 X 135 \mathrm{~cm})$ with nylon gauze sides. To maintain the predator culture, a suitable number of the prey was daily offered to the predator (Mangoud et al., 2013). 


\section{Egg picking}

The method for egg laying [black polyethylene strips fixed inside a plastic cylindrical $(10 \mathrm{~cm}$ length X $2 \mathrm{~cm}$ diameter) for laying eggs and put in the rearing pots]. After laid egg-masses, they were removed from plastic cylinders to separate the egg-masses from the cylindrical plastic and to be ready to stick on the carton paper card for releasing. The plastic cylinder was checked twice/day for egg-masses because of the cannibalistic habits of the adults, especially when there was a shortage of host food. In order to provide the developing larva with sufficient food throughout their developmental period, it was necessary to increase the amount of food with the advancement of their development (Mangoud and Mahyoub, 2013).

\section{RELEASE OF C. SEPTEMPUNCTATA}

Releasing study was conducted on alfalfa plants grown in Jeddah City during February of the two successive years (2012 and 2013). The selected plants for the present investigation were away from any pesticide contamination. An area of $1 / 4$ feddan of each crop was divided into 20 plots, each of approximately $50 \mathrm{~m}^{2}$. The plots were arranged in randomized block with four replicates for each treatment, and another four replicates as control.

Naturally, the numbers of C. septempunctata stages were rare, therefore, three levels of $C$. septempunctata eggs; first level consists of 30 eggs (one card), second level consists of 60 eggs (two cards) and the third one consists of 90 eggs (three cards) were released to encouragement the normal predator population to reduce the aphid. C. septempunctata were released (one time), by the beginning of February on alfalfa plants in 2012 season and repeated in the same time in 2013 season.

Samples were randomly taken bi-weekly and counting started from the beginning February in alfalfa plants. Twenty new leaves were examined in the field was made by a hand lens for counting the alive insects and their predators. Both surfaces of the leaf were inspected for the presence of aphid (Mangoud, 2000).

\section{STATISTICAL ANALYSIS}

The percent reduction of aphid after C. septempunctata released was calculated according to Henderson and Tilton equation (1955).

The data was subjected to analysis of variance (ANOVA) and the means were compared by L.S.D. test at 0.05 level, using SAS program (SAS Institute, 1988).

\section{RESULTS AND DISCUSSION}

The seven-spotted ladybug, C. septempunctata L. lives in a wide variety of habitats. Any place where there are plants and aphids may attract these species (Fleming, 2000).

\section{RELEASE OF C. SEPTEMPUNCTATA}

Three levels of C. septempunctata eggs; first level (30 eggs on one card), second level (60 eggs on two cards) and the third level (90 eggs on three cards) were released (one time), by the beginning of February during 2012 and 2013 on alfalfa m2,s.

\section{First year (2012)}

\section{First level of release (30 eggs $/ \mathrm{m}^{2}$ )}

In first level of release ( $30 \mathrm{eggs} / \mathrm{m}^{2}$ ), the pre-count of $B$. brassicae was 75 individuals $/ \mathrm{m}^{2}$ in releasing area, while it was 73 individuals $/ \mathrm{m}^{2}$ in check (control).

The results in Fig. (1) indicated that the number of $B$. brassicae in the $1^{\text {st }}$ release plot decreased gradually from 75 on the $1^{\text {st }}$ February to 60, 57, 52, 50 and 48 individuals $/ \mathrm{m}^{2}$, on mid-February, first-March, mid-March, firstApril and mid-April, respectively as compared to check plot (aphid populations changed from 73 individuals/ $\mathrm{m}^{2}$, on first-February to 79, 84, 91, 98 and 105 individu$\mathrm{als} / \mathrm{m}^{2}$, in the same dates, respectively). In addition, the results show that the percent reduction of $B$. brassicae in $1^{\text {st }}$ release plot increased gradually to reach $26.1,34.0$, 44.4, 50.3 and 55.5\% on mid-February, first-March, mid-March, first-April and mid-April, respectively.

\section{Second level of release (60 eggs $/ \mathrm{m}^{2}$ )}

In second level of release (60 eggs $\left./ \mathrm{m}^{2}\right)$, the pre-count of $B$. brassicae was 71 individuals $/ \mathrm{m}^{2}$ in releasing area, while it was 69 individuals $/ \mathrm{m}^{2}$ in check (control).

The results in Fig. (1) indicated that the number of $B$. brassicae in the $2^{\text {nd }}$ release plot decreased gradually from 71 on the $1^{\text {st }}$ February to 52, 48, 39, 28 and 19 individuals $/ \mathrm{m}^{2}$ on mid-February, first-March, mid-March, firstApril and mid-April, respectively as compared to check plot (aphid populations changed from 69 individuals/ $\mathrm{m}^{2}$, on first-February to 74, 82, 88, 93 and 99 individuals $/ \mathrm{m}^{2}$, in the same dates, respectively). In addition, the results show that the percent reduction of $B$. brassicae in $2^{\text {nd }}$ release plot increased gradually to reach $31.7,43.1$, 56.9, 70.7 and 81.3\% on mid-February, first-March, midMarch, first-April and mid-April, respectively.

\section{In third level of release (90 eggs $/ \mathrm{m}^{2}$ )}

In third level of release, the pre-count of $B$. brassicae was 65 individuals $/ \mathrm{m}^{2}$ in releasing area, while it was 61 individuals $/ \mathrm{m}^{2}$ in check (control).

The results in Fig. (1) indicated that the number of $B$. brassicae in the $3^{\text {rd }}$ release plot decreased gradually from 65 on the $1^{\text {st }}$ February to 42, 37, 30, 20 and 


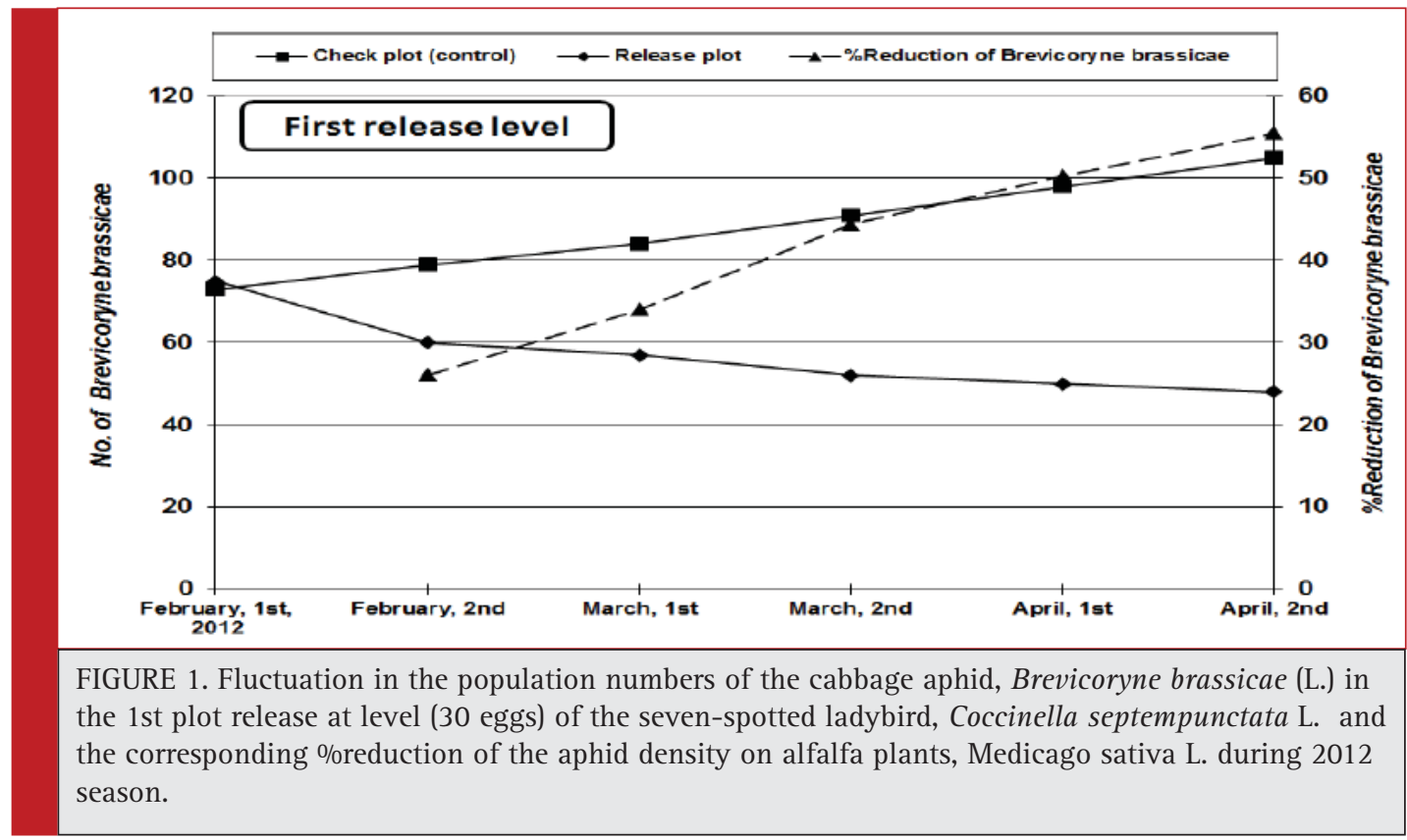

11 individuals $/ \mathrm{m}^{2}$, on mid-February, first-March, midMarch, first-April and mid-April, respectively as compared to check plot (aphid populations changed from 61 individuals $/ \mathrm{m}^{2}$, on first-February to $68,75,88$, 94 and 101 individuals $/ \mathrm{m}^{2}$, in the same dates, respectively). In addition, the results show that the percent reduction of $B$. brassicae in $3^{\text {rd }}$ release plot increased gradually to reach $42.0,53.7,68.0,80.0$ and $89.8 \%$ on mid-February, first-March, mid-March, first-April and mid-April, respectively.

These results are in agreement with those obtained by Mangoud, (2009) the seven-spotted ladybird, Coccinella septempunctata L. (Coleoptera: Coccinellidae) is an important predator of aphids play a good role in reducing the population density of the woolly apple aphid, Eriosoma lanigerum (Hausmann) (Homoptera : Aphididae) attacking apple trees.

\section{Second year (2013)}

Also, three levels of $C$. septempunctata eggs; first level (30 eggs on one card), second level (60 eggs on two cards) and the third level (90 eggs on three cards) were released (one time), by the beginning of February on alfalfa plants during 2013.

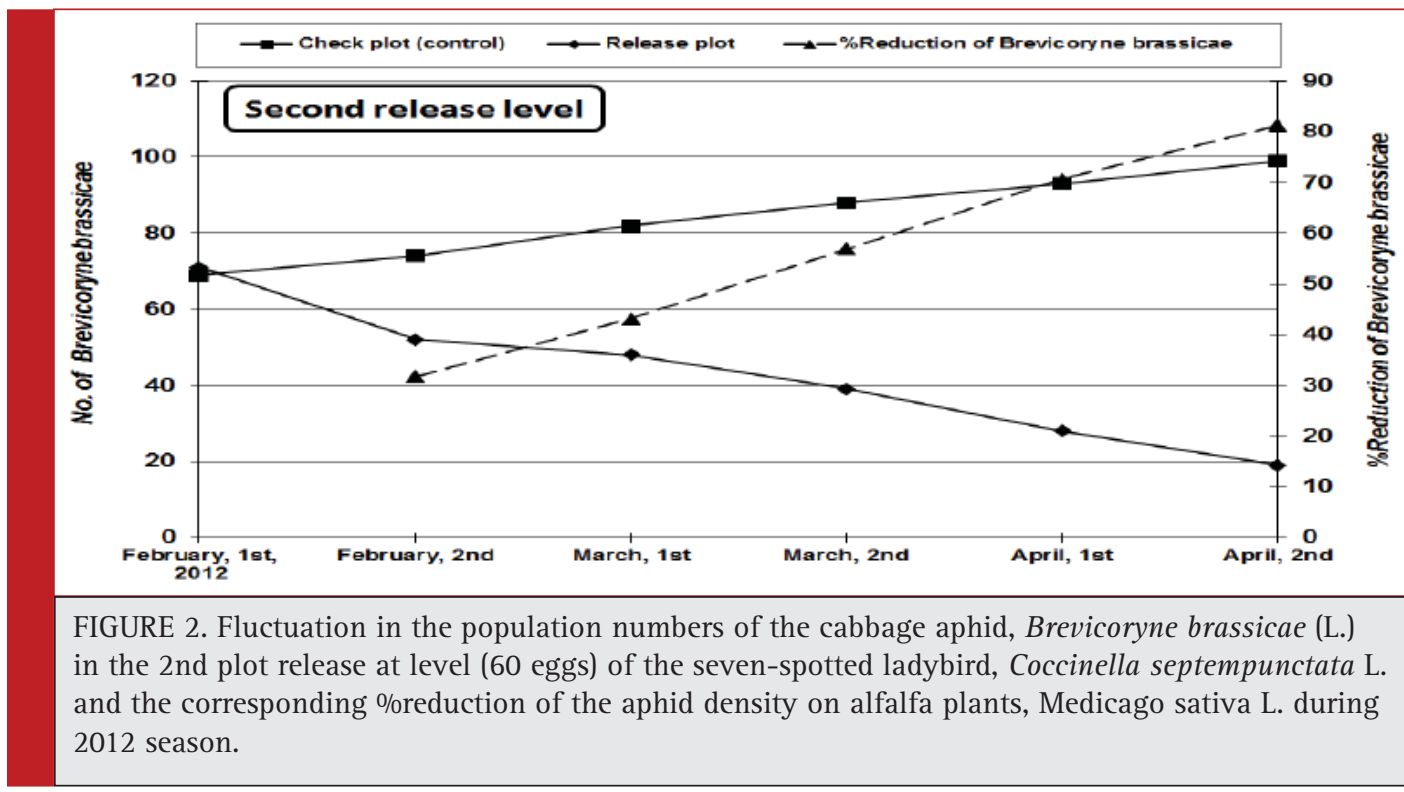




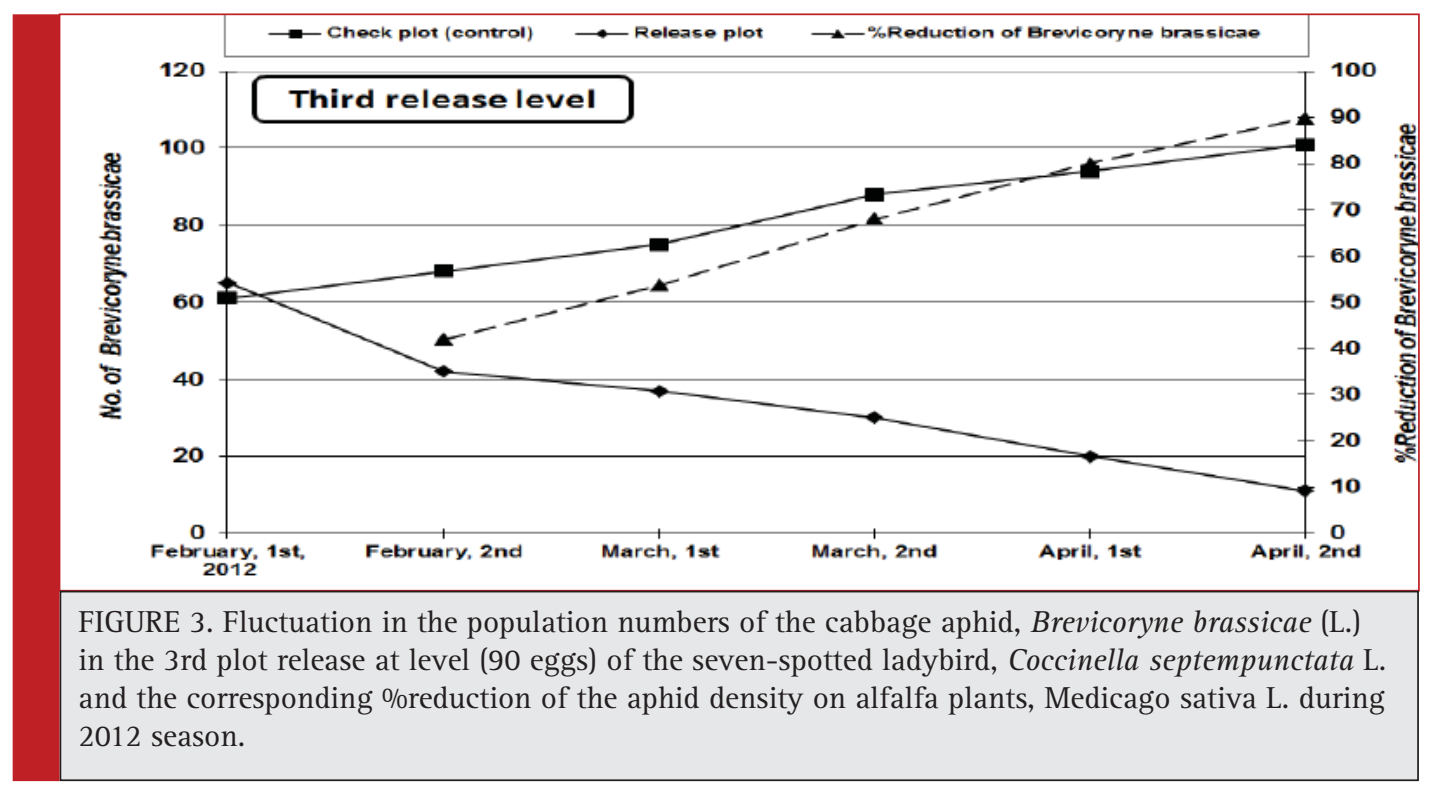

\section{First level of release (30 eggs $/ \mathrm{m}^{2}$ )}

In first level of release (30 eggs $\left./ \mathrm{m}^{2}\right)$, the pre-count of $B$. brassicae was 81 individuals $/ \mathrm{m}^{2}$ in releasing area, while it was 85 individuals $/ \mathrm{m}^{2}$, in check (control).

The results in Fig. (2) indicated that the number of $B$. brassicae in the $1^{\text {st }}$ release plot decreased gradually from 81 on the $1^{\text {st }}$ February to $65,63,54,48$ and 45 individuals $/ \mathrm{m}^{2}$, on mid-February, first-March, mid-March, firstApril and mid-April, respectively as compared to check plot (aphid populations changed from 85 individuals $/ \mathrm{m}^{2}$, on first-February to 92, 99, 103, 109 and 121 individu$\mathrm{als} / \mathrm{m}^{2}$, in the same dates, respectively). In addition, the results show that the percent reduction of $B$. brassicae in $1^{\text {st }}$ release plot increased gradually to reach 25.9, 33.2, 45.0, 53.8 and $61.0 \%$ on mid-February, first-March, midMarch, first-April and mid-April, respectively.

\section{Second level of release (60 eggs $/ \mathrm{m}^{2}$ )}

In second level of release (60 eggs $\left./ \mathrm{m}^{2}\right)$, the pre-count in the releasing area with $B$. brassicae 79 individuals $/ \mathrm{m}^{2}$, while it was also 74 individuals $/ \mathrm{m}^{2}$ in control (check).

The results in Fig. (2) indicated that the number of $B$. brassicae in the $2^{\text {nd }}$ release plot decreased gradually from 79 on the $1^{\text {st }}$ February to 57, 51, 43, 29 and 19 individu-

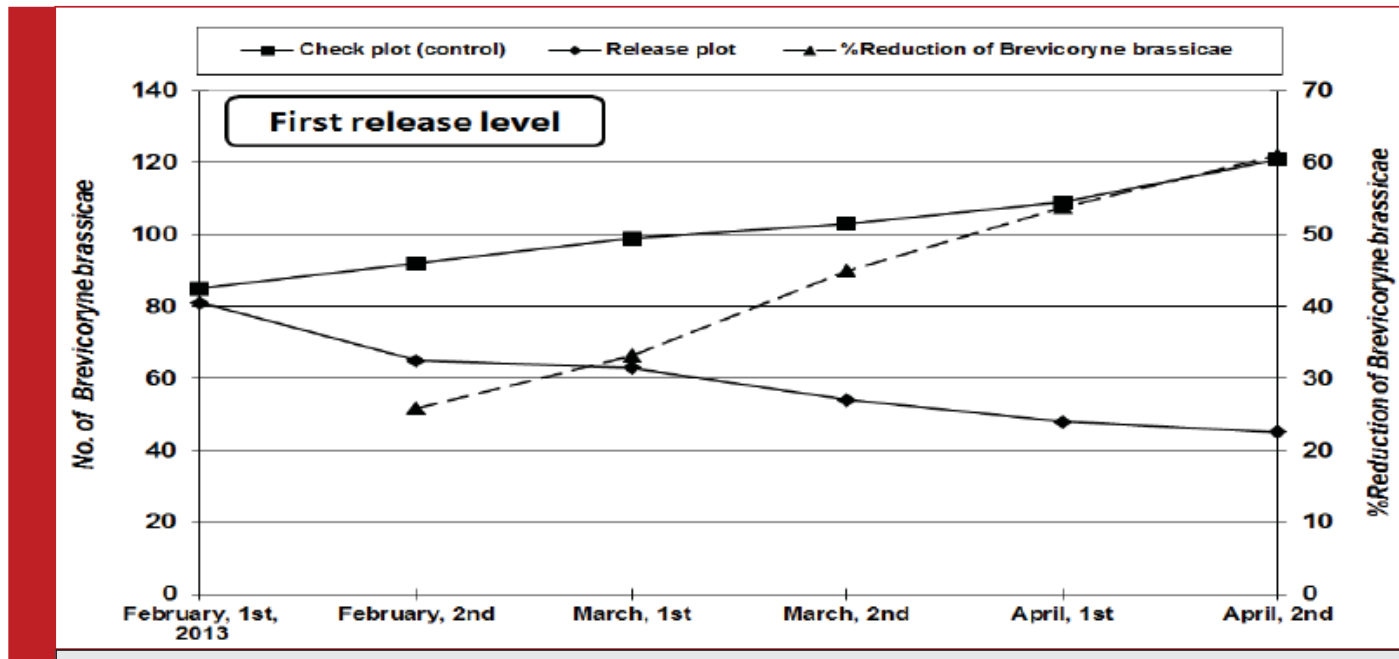

FIGURE 4. Fluctuation in the population numbers of the cabbage aphid, Brevicoryne brassicae (L.) in the 1 st plot release at level (30 eggs) of the seven-spotted ladybird, Coccinella septempunctata $\mathrm{L}$. and the corresponding \%reduction of the aphid density on alfalfa plants, Medicago sativa L. during 2013 season. 


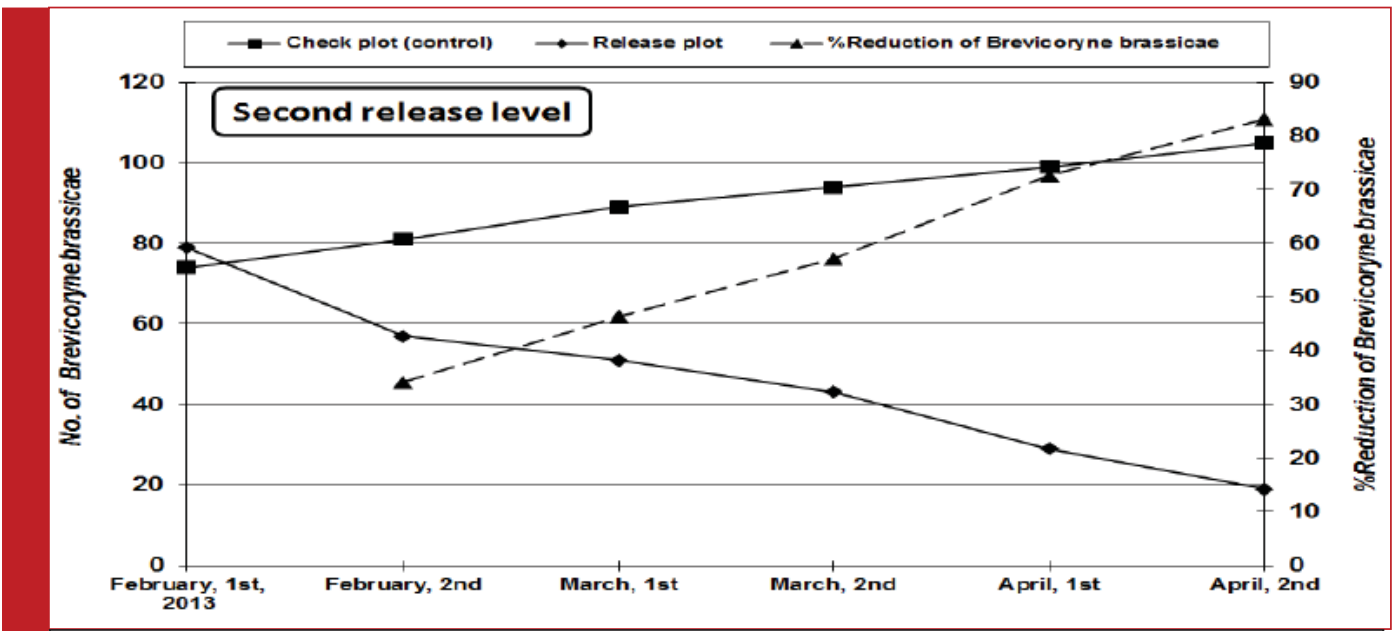

FIGURE 5. Fluctuation in the population numbers of the cabbage aphid, Brevicoryne brassicae (L.) in the 2 nd plot release at level (60 eggs) of the seven-spotted ladybird, Coccinella septempunctata L. and the corresponding \%reduction of the aphid density on alfalfa plants, Medicago sativa L. during 2013 season.

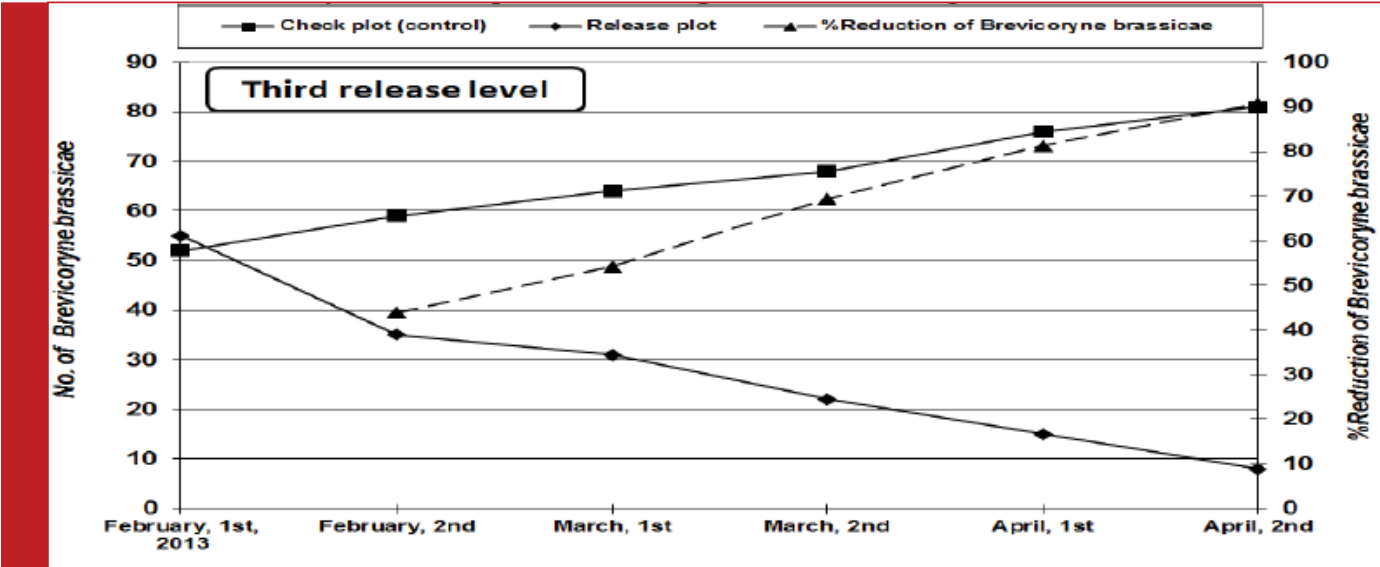

FIGURE 6. Fluctuation in the population numbers of the cabbage aphid, Brevicoryne brassicae (L.) in the 3rd plot release at level (90 eggs) of the seven-spotted ladybird, Coccinella septempunctata L. and the corresponding \%reduction of the aphid density on alfalfa plants, Medicago sativa L. during 2013 season.

Table 1: Percent reduction of the cabbage aphid, Brevicoryne brassicae (L.) after releasing the seven-spotted ladybird, Coccinella septempunctata $\mathrm{L}$. on alfalfa plants, Medicago sativa L. plots during 2012 and 2013 seasons.

\begin{tabular}{|l|l|l|}
\hline Level of release & $\begin{array}{l}\text { Reduction\% } \\
\text { during 2012 }\end{array}$ & $\begin{array}{l}\text { Reduction\% } \\
\text { during 2013 }\end{array}$ \\
\hline 1st & 55.5 & 61.0 \\
\hline 2nd & 81.3 & 83.1 \\
\hline 3rd & 89.8 & 90.7 \\
\hline F 0.05 & $148.3^{* * * *}$ & $293.2^{* * *}$ \\
\hline LSD & 1.41 & 1.14 \\
\hline
\end{tabular}

als $/ \mathrm{m}^{2}$ on mid-February, first-March, mid-March, firstApril and mid-April, respectively as compared to check plot (aphid populations changed from 74 individuals/ $\mathrm{m}^{2}$, on first-February to $81,89,94,99$ and 105 individuals $/ \mathrm{m}^{2}$, in the same dates, respectively). In addition, the results show that the percent reduction of $B$. brassicae in $2^{\text {nd }}$ release plot increased gradually to reach $34.1,46.3$, 57.2, 72.6 and $83.1 \%$ on mid-February, first-March, mid-March, first-April and mid-April, respectively.

\section{In third level of release ( $90 \mathrm{eggs} / \mathrm{m}^{2}$ )}

In third level of release, the pre-count in the releasing area with $B$. brassicae 55 individuals $/ \mathrm{m}^{2}$, while it was also 52 individuals $/ \mathrm{m}^{2}$ in control (check). 
The results in Fig. (2) indicated that the number of $B$. brassicae in the $3^{\text {rd }}$ release plot decreased gradually from 55 on the $1^{\text {st }}$ February to 35, 31, 22, 15 and 8 individuals $/ \mathrm{m}^{2}$, on mid-February, first-March, mid-March, firstApril and mid-April, respectively as compared to check plot (aphid populations changed from 52 individuals/ $\mathrm{m}^{2}$, on first-February to 59, 64, 68, 76 and 81 individuals $/ \mathrm{m}^{2}$, in the same dates, respectively). In addition, the results show that the percent reduction of $B$. brassicae in $3^{\text {rd }}$ release plot increased gradually to reach 43.9, 54.2, 69.4, 81.3 and 90.7\% on mid-February, first-March, mid-March, first-April and mid-April, respectively.

Statistical analysis show highly significant differences between the three releasing levels (30, 60 and 90 eggs/ replicate) of $C$. septempunctata predator in reduction $B$. brassicae $(\mathrm{F}=148.3, \mathrm{P}>0.05$ and LSD was 1.41 , respectively during 2012 year). Also, during 2013 year statistical analysis show highly significant differences between the three releasing levels (30, 60 and 90 eggs/replicate) of C. septempunctata predator in reduction $B$. brassicae $(\mathrm{F}=$ 293.2, $\mathrm{P}>0.05$ and LSD were 1.14) (Table 1).

These results are in agreement with those obtained by Mangoud (2013) who stated that the seven-spotted ladybird, Coccinella septempunctata L. (Coleoptera: Coccinellidae) is an important predator of aphids play a good role in reducing the population density of the green peach aphid, Myzus persicae and the cotton aphid, Aphis gossypii (Hausmann) (Homoptera : Aphididae) attacking apple trees.

These results are in harmony with those obtained by Hoyt and Madsen (1960) found that the control of aphid species complex is complicated by the continue dispersal of aphids from the roots to the aerial portions of the tree, and a corresponding dispersal in the opposite direction. Release C. septempunctata adopted here can cope very well with this behaviour. Brar and Kanwar (1994) in field experiments in India found Coccinella septempunctata was an effective predator against Aphis craccivora infesting fenugreek germplasm. El-Aish et al. (2004) demonstrated the role of the predator $C$. septempunctata in biological suppressing of cereal aphids and showed that the eggs lasted 2-3 days and the 1st, 2nd, 3rd and 4th larval instars lasted 3, 2, 2 and 4 days, respectively, the pupal stage lasted 8 days at the room temperature. The adult predator consumed 46.13 aphids, while the larval consumed 26.9 aphids daily. Fang et al. (1984) found the coccinellids, $C$. septempunctata to be good controllers of $B$. brassicae in cotton fields at yellow Rever valley in China.

\section{AKNOWLEDGEMENTS}

The authors are indebted to deanship of Scientific Research - King Abdulaziz University for funding this research and for providing the facilities to carry out this research work. We are also thankful to all our colleagues and friends in Hada Al-Sham research station for their co-operation and encouragement during this work.

\section{REFERENCES}

Anonymous (1997): Ladybird Beetle. Microsoft Encarta 97 Encyclopedia. Houghton Mifflin Company.

Arnett J.; N. M. Ross; and H. E. Jaques (1980): How To Know The Beetles. W. C. Brown Company Publishers, Dubuque, Iowa.

Bilashini, Y.; Singh, T. K. and Singh, R. K. R. (2007): Biological control potential of Coccinella septempunctata Linnaeus (Coleoptera: Coccinellidae) on major homopteran pests of rapeseed. J. Biological Control, 21, 157-162.

Brar, K. S. and J. S. Kanwar (1994): Management of Aphis craccivora infesting fenugreek germplasm. Punjab-VegetableGrower, 31: 41-44.

Brunt, A.; Crabtree, K.; Dallwitz, M.; Gibbs, A.; Watson, L. and Zurcher, E. (1996): M2, Viruses Online: Description and Lists from the VIDE Database. http://biology.anu. edu.au/ Groups/ MES/vide.

Buchen-Osmond, C. (2002): The Universal Virus Database of the International Committee on Taxonomy of Viruses. http:// phene. cpmc.columbia.edu/Wlinky/index.html.

El-Aish, H. S., El-Ghariani, I. M. and Al-Mabruk, A. H. (2004): Survey of cereal aphids and their natural enemies and effect of the predator Coccinella septemunctata on biological suppression of cereal aphids in Al-Jabal Al-Akhdar Region, Libya. Proceeding of 1st Arab Conference or Applied Biological Pest Control, Cairo, Egypt, 5-7 April 2004. Egyptian J. of Biol. Pest Cont., 14(1): 285-290.

Fang, C. Y., Wen, S. G., Cul, S.Z. and Wang, Y. H. (1984): The role of natural enemies in the integrated control of insect pests on cotton. China cotton, 2: 42-43.

Fleming, R. C. (2000): Entomology Notes 6: Lady Beetles. http://insects.ummz.lsa.umich.edu/MES/notes/entnotes6.html.

Hafez, M. (1961): Seasonal fluctuations of population density of the Cabbage aphid, Brevicoryne brassicae (L.) in the Netherlands, and the role of its parasite, Aphidius Diaretiella rapae (CURTIS). Tijdschr. Plziekt. 67: 445-548.

Hendrson, C.F. and E.W. Tilton (1955): Test with acaricides against the brown wheat mite. J. Econ Entomol., 48: 157-161.

Hoyt, S. C. and H.F. Madsen (1960): Dispersal behavior of the first instar nymphs of the woolly apple aphid. Hilgardia, 30: 267-297.

Ibrahim, M.M. (1948): The morphology and anatomy of Coccinella undecimpunctata aegyptiaca Reiche. Bull. Soc. 1er Entom., XXXII: 305-316

Ibrahim, M.M. (1955): Studies on Coccinella undecimpunctata aegyptiaca Reiche. I. Preliminary notes and morphology of the early stages. Bull. Soc. Entom., Egypt, XXXIX, : 251-274.

Lundgren, J. G. (2009). Relationships of natural enemies and non-prey foods. Springer International, Dordrecht, The Netherlands. 
Mangoud, A. A. H. (2000): Integrated pest management of apple trees. Ph. D. Thesis, Fac. Agric. Cairo Univ. Cairo, Egypt, $225 \mathrm{pp}$.

Mangoud, A. A. H. (2003): Research work on mass rearing of predators during working in the Project 604 "Mass rearing of parasites and predators attacking mealybugs and whiteflies".

Mangoud, A. A. H. (2009): Manipulation of the seven spotted lady beetle, Coccinella septempunctata (Coleoptera : Coccinellidae) for controlling the woolly apple aphid, Eriosoma lanigerum (Homoptera : Aphididae). Egypt, J. Agric. Res., 85 (2): 441-451.
Mangoud, A. A. H. \&t Mahyoub, J. A. (2013): Mass production the seven spotted lady beetle, Coccinella septempunctata (Coleoptera : Coccinella) and suitable manipulation of picking (in press)

SAS Institute 1988. SAS/STAT User's Guide, Ver. 6.03. SAS Institute Inc., Cary, North Carolina.

Theunissen, N. (1989): Integrated control of aphids on fieldgrown vegetables. In: Aphids, their biology, natural enemies and control. Vol. C. (Eds.: A.K. Minks, P. Harrewijin), pp. 285-289.

Waldbauer, G. (1998): The Birder's Bug Book. Harvard University Press, Cambridge, Massachusetts. 